\title{
THE MAINTENANCE OF GORONTALO LANGUAGE THROUGH TEACHING THE LOCAL CONTENT AT ELEMENTARY SCHOOLS
}

\author{
Moon H. Otoluwa ${ }^{1}$, Zulkifli Tanipu ${ }^{2}$, Novi Rusnarty Usu $^{3}$, Rasuna Talib ${ }^{4}$ \\ Universitas Negeri Gorontalo \\ moon_hidayati@yahoo.co.id, ${ }^{1}$ zulkifli_ung@yahoo.com, ${ }^{2}$ noviusu@gmail.com, ${ }^{3}$ \\ rasuna68@yahoo.com ${ }^{4}$
}

\begin{abstract}
The current condition exposes the degradation of number of speakers even the use of Gorontalo language. It is proved by the data which show that almost $40 \%$ of respondents cannot speak Gorontalo language actively. As a consequence, the maintenance of Gorontalo language is a must to prevent this phenomenon to be worse. One of the effective ways to maintain Gorontalo language is teaching the Gorontalo language through the local content at elementary schools. Moreover, the teaching process should involve cultural and linguistic aspects of the language.
\end{abstract}

Keywords: language maintenance, local content, linguistics

It is a fact that language has a strong relationship with culture even civilization of language users. Language also is a storage device of culture that is owned by the speakers of language while culture includes customs, value systems, even the rules that govern the lives of the speech community. Regarding its historical function, language is also an authentic proof of the existence of a civilization that was born and developed in a society. The history and development of civilization were recorded through a language and conveyed from one generation to another by using the language as a medium. In other words, language is an important component of group identity (see Cavallaro, 2005; Fought, 2006). It means that language is not only a medium of transferring idea and medium of communication but also the identity of a community. The language we speak is part of our identity as individuals and makes us part of our community.

One of languages which convey the crucial role to maintain the culture and civilization is local language. Local languages prove the existence of a transformation of a society in terms of spoken and written forms of language and culture. Therefore, the local language can be defined as a system of knowledge in which there is the value that is owned by the community and it affects people's behavior. Consequently, if the language of the region shifted, possibly it signifies a value shift either the way of life, social behavior, or anything else that is actually a characteristic of their culture. Even more, Hale (1992, p. 36) insists that the loss of local languages and "the cultural systems they represent" represents a loss of intellectual and cultural wealth, and the "products of human mental industry"; thus by letting local languages die we are letting go of a wealth of information encoded in those languages.

On the other hand, as a consequence of the development of language and society, local language tend to decrease in terms of its users and its use. This phenomenon occurs globally 
where Krauss (1992) predicts that as many as 95\% of the world's estimated 6000 languages will be lost in this century. It can be caused by the shift of language onto new language or even foreign language. Language shift is the process by which a speech community in a contact situation (i.e. consisting of bilingual speakers) gradually stops using one of its two languages in favor of the other (Ravindranath, 2009, p. 1). This phenomenon will be even worse when the society do not play their role and the government does not codify the language plan and language policy which fit the local condition.

There are several causal factors of this phenomenon, the language shift or even language death, but the most crucial thing is the language attitude of its speakers/users. The causal factors of language shift are generally considered to be social either internal or external factor. The current example of language shift is when local languages nowadays rarely used by its speakers particularly the young generation. They tend to use Malay language even foreign language such as English and Korean rather than their own local language. It can be seen from the number of local languages in Indonesia which is getting decreased year by year which indicates the decreasing of local languages' speakers. This problem has been crucial since there has not been any government policies to overcome.

The big question of this phenomenon is whether the young generation play the role in the decreasing of local languages or do we have another cause? Are they incapable of using local languages? Actually, the main problem is not that young generation are incapable of using their local language, but it is their willingness that have lost. Nowadays, they grew up in a society that their standard of living through media, and what they see in the media are what percept to be right and up-to-date is. As human being, it is just natural wanting to be the best version of us, and sadly what is perceived to be the best nowadays is our ability to blend in society, not to stand with our own uniqueness and identity. And blending in the society nowadays stand on, as an example, our ability to speak as many foreign languages rather than our local, native mother tongue.

Language, however, is our first card in playing the game of self-actualization; physical appearance might be the first to be noticed by others, but it's the moment we start to open our mouth and speak, that really tell a lot about our self-worth. The challenge now, as a consequence, it is a must to make people speak of local language because they proud of it, that somehow speaking in local languages will improve their confidence and pride among others. Take Javanese language as an example. Having conversation in ancient, high ranked Javanese are accepted as a gesture of nobility, respectful, elegant, and cultured people. Parents teach their children that you must only speak using local language in a respectful fashion, that it is somehow what attracts people to your own self-worth, that local language could be used as a tool in everyday language as well as part of pop culture easily found in movies, music, and any kind of modern arts. Only when we could conceives the society especially the youngsters that local language does not equal quirky, out of date, and only used by uneducated people that you can also be proud by speaking locals and proud of your culture; that people will eager to learn their own language with as much passion as the show in learning others, and thus, the local language would be naturally preserved without too much interventions by our government just like what they did in the past; desperately try to put it as a part of formal education at school.

Regarding this situation, we believe in it or not, if we do not play our last card to prevent this phenomenon into the worst, it is only a matter of time that local languages will be perfectly shifted to be extinct languages because language shift that occurs continuously will cause the extinction of language. The extinction of languages does not only cause the extinction of cultural heritage of a country, but most importantly it is the loss of culture, value 
system, even civilization of a society. Austin \& McGill (2012) insist "because every last word means another lost world" which means that a death of a language, local language in particular will cause a devastation of human kind because local languages are the cultural tools to preserve world civilization. So that, to overcome this phenomenon, various parties have to plan a language preservation system particularly the preservation of local languages in Indonesia.

\section{Current Problem of Local Language in Gorontalo}

One of languages that increasingly shifts and tends to decrease in terms of the number of speakers and the use is the Gorontalo language. Gorontalo language is one of heritage and local culture elements and even local culture storage devices which should be pursued and maintained in various social changes today. Social change is accompanied by an increasingly rapid global developments which has various implications on the existence of the decreasing of Gorontalo language. This phenomenon can be seen from the decline in the number of active speakers of the language Gorontalo and of course also followed by a decrease in the use of language Gorontalo especially by the younger generation in Gorontalo.

Research data show that the significant decreasing of speakers is at the age of $0-20$ years. Compare to the speakers at the age of $21-40$, most of these youngsters can only understand Gorontalo language but they are not capable enough of speaking the language actively. This following table indicates the dramatic phenomenon regarding the descent of speakers of Gorontalo language particularly the young generation.

Table 1. The use of Gorontalo Language

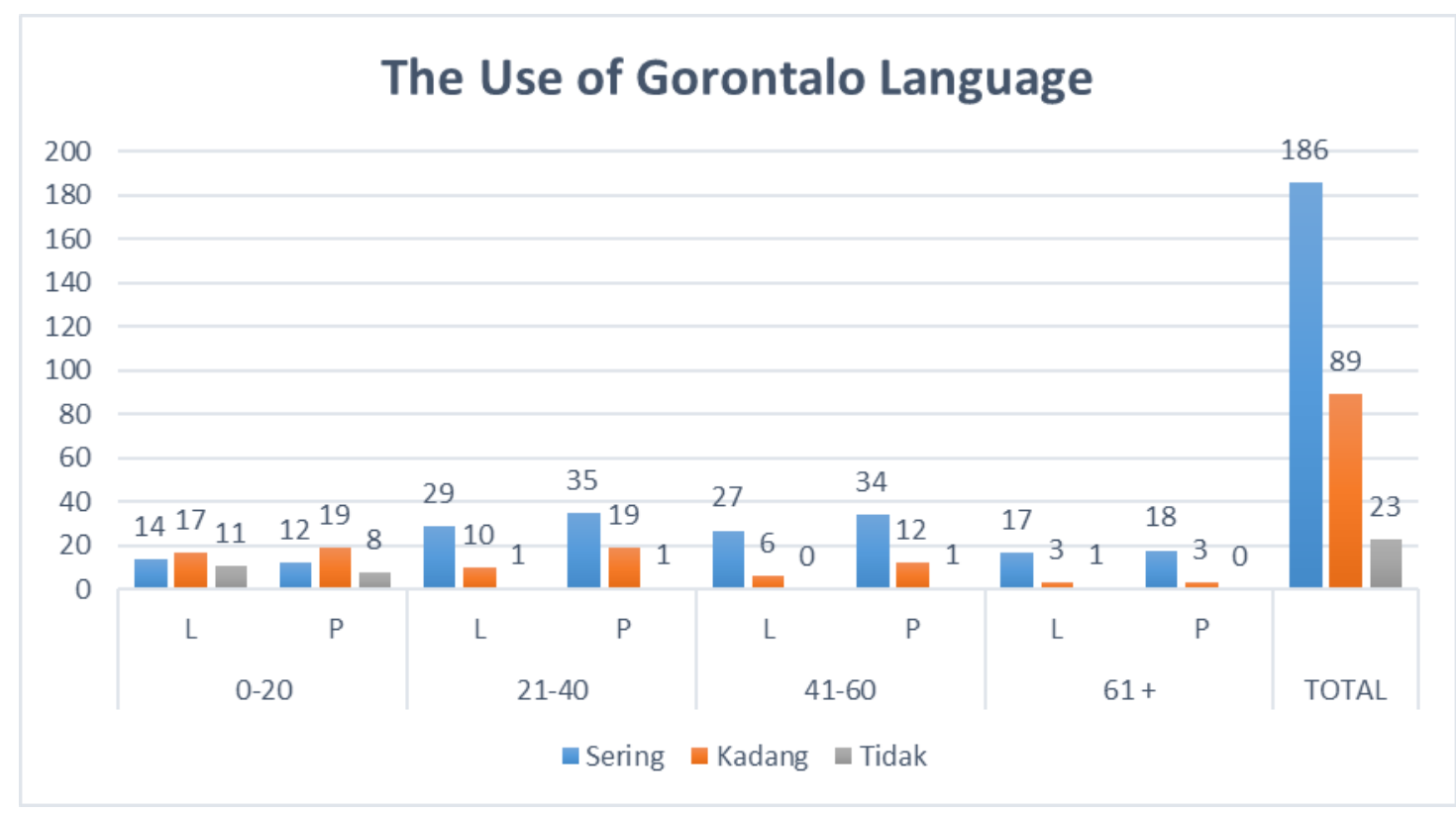

Note: L : Male Kadang : Sometimes

$\mathrm{P} \quad$ : Female Tidak : Never

Sering : Often

Some opinions of experts, practitioners and observers of Gorontalo language also agree with the argument that the language Gorontalo tend to decrease particularly the number of 
active speakers. Collins (2012) in the International Conference on Language and Literature at the State University of Gorontalo found that Gorontalo language currently is in danger. It is caused by several factors such as language Gorontalo is no longer upheld by its speakers. Gorontalo people tend not to symbolize themselves through the language of Gorontalo. This corresponds with the independence of Gorontalo from North Sulawesi province. In fact, from his observations in social networks, such as Facebook, young people do not use Gorontalo language, they use Malay Gorontalo

In addition, families in Gorontalo tend to use Malay Gorontalo in daily communication. This results the exposure of Gorontalo language dramatically low. This affects the level of Gorontalo language acquisition by the younger generation which is also low. It also occurs in educational institutions, either formal or non-formal. Malay used as the language of instruction in educational institutions so that Gorontalo language cannot be mastered by the students. Moreover, the design of local curriculum for elementary schools more focused on the English subjects.

In terms of maintaining and developing the Gorontalo language, Collins suggested that educational institutions should increase the exposure of Gorontalo language in oral literature and then display it in electronic media such as websites. However, there is another thing to do regarding the language maintenance along-side the documentation of manuscript. In some extents the young speakers should increase their effort to use Gorontalo language. Moreover, the stakeholders need to encourage young people to use the language through various mediums, such as Facebook, SMS, email, or even through Youtube channel. Collins also recommended the government to make competitions of modern songs in the language of Gorontalo. The government of Gorontalo also should utilize technology particularly modern technology that is used by younger generation in everyday life. It is necessary to apply a comprehensive approach to formulate the design of Gorontalo language preservation. The steps of this effort should be done with a scientific approach that is measurable and wellplanned so that this effort can make Gorontalo language to be the lingua franca for the people of Gorontalo.

Regarding the effort of language maintenance in Gorontalo, this paper offers the way to prevent the degradation of the users of Gorontalo language which should be implemented through teaching and learning process in formal educational institutions particularly in elementary schools. Elementary schools are chosen based on several considerations which are 1) teaching language as early as possible is the best way to increase people's language skills and language awareness, 2) elementary schools are institutions which have much more opportunities to teach local language for students through local content subject, and 3) teachers in elementary schools would be able to codify the design of teaching and learning process by involving inter-cultural aspects of language. These factors are taking into account because they are crucial in terms of the process of involving schools as the formal educational institutions in the whole process of language maintenance.

\section{Concept of Language Maintenance}

Fishman in Hornberger, 2006 stated that the study of language maintenance and language shift is concerned with the relationship between change (or stability) in language usage patterns, on the one hand, and ongoing psychological, social or cultural processes, on the other hand, in populations that utilize more than one speech variety for intra-group or for inter-group process. It is scientifically interesting because the issues of language degradation has been dramatically increased in these few recent years. 
In general, language maintenance is defined as the decision to continue the use of languages collectively by a community that has used such language for long time (Fasold: 1984). Furthermore, Fasold also states that the preservation of this language is the opposite or different sides of the shift in language; ie where a community decides to replace the language that has been used or choose another language instead of the language that has been used. In other words, language maintenance can be defined as the effort to continually use the ethnic or local language. The users of local language have the willingness to use their local language then use it continually with a good language awareness. They aware that the local language is their identity so that it should be maintained in order to maintain their civilization. In terms of maintaining the use of local language, the government should be involved actively by encouraging the users of language to use local language in all extents of communication levels.

The implementation of language maintenance should consider the grand design of language policy codified by government, either central or local government. Language policy in particular can be defined as a set of measures that countries have adopted to regulate language use within their territories. In order to be effective, it is necessary to distinguish clearly between state language, official language, national language and regional or minority languages, and to define their specific social roles (Das, 2004; Mar-Molinero 2000). This is very important so that the government can put each language based on their specific roles because the appropriate policy from government can easily help people to involve in the effort of language maintenance and preservation.

It takes a strong commitment to the effort of language preservation. This is because the level of advancement of knowledge and technology in society has already increased and more exposure of foreign languages on people's daily lives. It can be seen from the rise of companies that include foreign language capabilities as key requirements to be their employees, not local language capabilities. It also takes place in education. Foreign language has become a compulsory subject as well as the main requirement of graduation. As a result, the exposure of local language has decreased in this recent dacade.

\section{Teaching Local Content through Inter-Cultural Learning to Maintain Gorontalo Language}

Meyer (1991) states that intercultural competence is the ability of a person to behave adequately and in a flexilble manner when confronted with actions, attitudes, and expectations of representative of foreign cultures. Moreover, Byram and Morgan (1994) claimed that those who understand more than one social identity and national culture, and who are capable of engaging in interaction with people from various cultural context are called intercultural speakers.

According to Barret (2011), below are following components form the core of intercultural competence:

\section{a. Attitudes}

Respect for other cultures; curiosity about other cultures; willingness to learn about other cultures; openness to people from other cultures; willingness tosuspend judgement; willingness to tolerate ambiguity; and valuing cultural diversity. 
b. Skills

Skills of listening to people from other cultures; skills of interacting with people from other cultures; skills of adapting to other cultural environments;linguistic, sociolinguistic and discourse skills, including skills in managingbreakdowns in communication; skills in mediating intercultural exchanges; skills in discovering information about other cultures; skills of interpreting cultures andrelating cultures to one another; empathy; multiperspectivity; cognitive flexibility;and skills in critically evaluating cultural perspectives, practices and products, including those of one's own culture.

c. Knowledge

Cultural self-awareness; communicative awareness, especially of the different linguistic and communicative conventions within different cultures; culture-specific knowledge, especially knowledge of the perspectives, practices and products of particular cultural groups; and general cultural knowledge, especially knowledge of processes of cultural, societal and individual interaction.

\section{d. Behaviours}

Behaving and communicating effectively and appropriately duringintercultural encounters; flexibility in cultural behaviour; flexibility in communicative behaviour; and having an action orientation, that is, a disposition for action in societyin order to enhance the common good, especially through the reduction of prejudice, discrimination and conflict.

Based on the core components of inter-cultural competence, this concept is actually implemented in teaching foreign language. But regarding the phenomenon that the position of local languages in some regions even some countries is almost similar with foreign language in terms of their use and number of speakers, this concept factually can be implemented in teaching local languages. It is important to have the comprehensive point of view of this concept so that this concept can be adapted into teaching local languages (Council of Europe, 1992) because local education systems play an important role in preserving minority and regional languages

Moreover, teaching local languages should be implemented by teaching the mutual understanding of culture not only the aspects of language. It is considered that teaching local language should involve the aspect of culture to reach the goals which is the increasing of number of speakers of local languages. We should change our common thought that teaching language is only the process of increasing students' language skills. Teaching local language nowadays is quite similar with teaching foreign language because the low exposure of local language. Regarding this, this paper promotes several points which can drive the teaching approach of local languages through local content subject.

- Teachers should consider that teaching language is also a process of transferring the cultural values, thoughts and ways of life so that teacher should teach the aspect of cultures in their teaching material and teaching process.

- Teachers should increase students' cultural awareness of local languages so that students can easily understand the cultural aspect of language.

- Teacher should make them realize that using local language is their identity.

- Teachers should increase students' ability in understanding and interpreting those aspects in their daily life. 
- Teacher should increase students' willingness in learning local language by making the classroom and teaching process interesting and enjoyable.

- Teachers and school management should create the eligible atmosphere for students to learn local language, make them be able to practice and use local language at school.

- Teacher should involve parents in encouraging students to learn and practice local language at home.

As the consequence of this effort, teachers, school management, government, parents, and society should be cooperative and working together, hand in hand to implement this program. Language maintenance is a must to preserve our language and culture even to preserve our civilization.

\section{Conclusion}

The number of speakers of Gorontalo language has decreased for few decades so that the need to preserve Gorontalo language is inevitable. It is crucial to maintain Gorontalo language and one of appropriate ways to preserve this local language is the maintenance through teaching the local content at elementary schools. This policy should be implemented immediately by involving cultural and linguistic aspects of the language.

\section{REFERENCES}

Austin, Peter K \& McGill, Stuart, Language Documentation and Description Volume 11. London: School of Oriental and African Studies, 2012.

Barret, M, Intercultural Competence, The European Wergeland Center, 2011.

Butler, M., Lee, S., \& Tippins, D, "Case-Based Methodology as an Instructional Strategy for Understanding Diversity: Preservice Teachers' Perceptions", Foreing Language Annals, Vol, 40. No.1, 2006.

Cavallaro, F. Language maintenance revisited: An Australian perspective. Bilingual Research Journal, 29(3), 561-583. Retrieved from http://dx.doi.org/10.1080/15235882.2005.10162852. (2005).

Council of Europe (1992). European Charter for Regional or Minority Languages. Available online: http://conventions.coe.int/Treaty/en/Treaties/html/148.htm.

Crystal, David Language Death, New York: Cambridge University Press, 2003.

Collins, James. T, “Bahasa Melayu sepanjang sejarah: Ditinjau dari dua perspektif”. In Proceeding of Konferensi Internasional Bahasa dan Sastra Melayu Tahun 2012. Gorontalo, 2012.

Das, A.K, Minority language laws in the EU: process and problem of policy implementation 27-28/2/2004 II Mercator International Symposium: Europe 2004: A new framework for all languages? Tarragona-Catalunya. Available online: www.ciemen.cat/mercator/pdf/simpalok.pdf. 2004.

Fasold, R, The Sociolinguistics of Society, Cambridge: Cambridge University Press, 1984.

Fought, C. Language and ethnicity. Cambridge, UK: Cambridge University Press, 2006.

Gobel, K., \& Helmke, A.. Intercultural learning in English as foreign language instruction: The importance of teachers' intercultural experience and the. Teaching and Teacher Education 26, p. 1571-1582, 2010. 
Hale, Ken, Michael Krauss, Lucille J. Watahomigie, Akira Y. Yamamoto, Colette Craig, LaVerne Masayesva Jeanne, and Nora C. England. "Endangered Languages." Language 68 (1): 1-42, 1992.

Holmes, Janet, An Introduction to Sociolinguistic, New York: Longman, 1992.

Krauss, Michael, “The world's languages in crisis.” Language 68(1): 4-24, 1992.

Mar-Molinero, C. The politics of language in the Spanish-speaking world: from colonization to globalization, London: Routledge, 2000.

Nancy, Hornberger (ED), Language Loyalty, Continuity and Change, Toronto: Multilingual Matters Ltd, 2006.

Ravindranath, Maya, Language Shift and the Speech Community: Sociolinguistic Change in a Garifuna Community in Belize, Pennsylvania: University of Pennsylvania, 2009. 